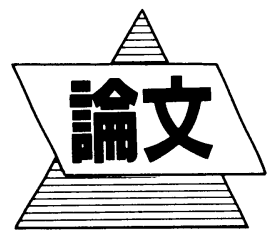

\title{
電子線照射を用いた 印刷抵抗の構成法
}

\section{町田 英夫*, 川上 伸，坂本 勇，小而林 敬***永田 秀俊***}

Electron Beam Applied Methods for Print-Resistor-Circuit

\author{
Hideo MACHIDA, Shin KAWAKAMI, Isamu SAKAMOTO,* \\ Takashi KOBAYASHI, ${ }^{* * *}$ Hidetoshi NAGATA ${ }^{* * *}$
}

\footnotetext{
*日本シイエムケイ株式会社（T 354 埼玉県入間郡三芳町藤久保 1106）

**日新ハイボルテージ株式会社（干 615 京都府京都市右京区梅津高畧町 47 ）

****東洋インキ製造株式会社開発研究所（广173 東京都板橋区加賀 1 丁目13-1）

* CMK Corporation (1106, Fujikubo, Miyoshi-machi, Iruma-gun Saitama 354)

** Nissin-High Voltage Co., Ltd (47, Umezu-Takase-cho, Ukyo-ku, Kyoto-shi, Kyoto 615)

*** Research \& Development Laboratory, Toyo Ink Manufacturing Co., Ltd (13-1, Kaga 1-chome, Itabashi-ku, Tokyo 173)
}

\begin{abstract}
概要 本論文は，プリント配線板の回路面にスクリーン印刷法を用いて抵抗体を印刷し，電子線照射(Electron beam) によりカーボンペーストを瞬時に硬化させる方式について述べたあのである。ての方式は電子線 の高いエネルギーを利用して電子線用ペーストを硬化し，定格電力 $1 / 32 \mathrm{~W}-50 \mathrm{~V}$ ，抵抗範囲 $100 \Omega \sim 100 \mathrm{k} \Omega$ の ノントリミング㓥抵抗を可能にしたあのである。
\end{abstract}

\begin{abstract}
This paper describes the manufacturing system of the printed circuitl boards with non trimming printed resistors by means of screen printing process on the pattern side.

Curing carbon paste can be done in a moment by using electron beam which is stronger enough compaired to X-ray and $r$-ray enabling to obtain non trimming printed resistors ranged from $100-\mathrm{ohm}$ till $100 \mathrm{k}$-ohm at rated $1 / 32 \mathrm{~W} 50 \mathrm{~V}$ by using it's energy with specially cured E. B. paste.
\end{abstract}

\section{1. はじめに}

従来行われてきたプリント配線板上に構成される 抵抗印刷基板においては，ほとんどが熱硬化性樹脂 を使用しているため, 硬化後に起てる構造変化によ ってトリミングが必要となったり，あるいは基材に 寸法変化, 反り, 歪み等の物理的な変化が起てり, 高密度化されていく回路にとって不都合な点が多々 あった。しかし，プリント配線板上にデスクリート 抵抗を搭載する方式では, 部品の購入・機械実装・ はんだ付け・チェック等, 繁雑な管理が必要である。 そのため, 抵抗をプリント配線板上に印刷によって 形成する事ができれば, 機器の信頼性の向上, 生産
コストの削減，板の小型化に寄与するてとができる。 抵抗印刷の問題点は，前述したでとく“熱”を使 用するととにある。筆者らは, 従来のプリント配線 板の加工工程においては全く使用されていない電子 線照射装置を用い, 従来の熱硬化工程における諸問 題を取り除くことに成功した。また，本論文で提案 する硬化方式はプリント配線板に広く使用されてい るすべての樹脂に適用することが可能である。

\section{2. 従来技術の問題点}

従来型のペーストは広く普及しつつあるが, 反面, 次のような問題点を内蔵していると考えられる。

（1） 1 枚の基板に数種類の抵抗ペーストを印刷する 
ため, 基板は $3 \sim 4$ 回繰り返して加熱される。この 加熱によって基板が伸縮し, その結果, 次工程にお ける部品の自動実装の歩留りが著しく悪くなる。特 に耐熱性の低い紙フェノール基板を用いた場合，そ の影響は大きい。

(2) 従来のペーストは溶剂を含んでおり，乙れが印 刷工程で蒸発するため, 版詰まりにより, 膜厚の変 動, 硬化後の抵抗值のバラッキ等の原因となり, 所 要の抵抗值を得るためにトリミングが必要である。

(3) 従来のペーストでは印刷後, 抵抗值を測定出来 るようになるまで数時間を要し，乙れを印刷工程に フィードバックして工程条件の調節を行おうとする 場合, 硬化炉中にあってロスとなる製品の量が多く 経済的でない。

これらの欠点を改良しょうとして電子線硬化型抵 抗ペーストの開発を行った。てのペーストは, 電子 線照射装置を通過させることにより, 瞬間的に硬化 するあのである。電子線で硬化する塗料, インキに ついては, わが国においてもかなり以前から研究さ れ, 鋼材, 建材, 紙製品の塗料印刷, 磁気記録材料 の製造等の分野で実用化されている。しかしながら， 本報で取り扱うような厚膜ペーストへの応用に関し

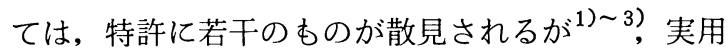
例は皆無である。

\section{3. 電子線照射による抵抗印刷法}

\section{1 電子線硬化用抵抗ペースト}

電子線硬化型抵抗ペーストは表 1 に示すような成 分を混練して製造した。

表 1. 電子線硬化型抵抗ペーストの組成 $(\Omega \mathrm{cm})$

\begin{tabular}{|l|c|c|c|}
\hline \multicolumn{1}{|c|}{ ペースト記号 } & $\begin{array}{c}\text { P-516L } \\
\text { (低抵抗) }\end{array}$ & $\begin{array}{c}\text { P-472L } \\
\text { (中抵抗) }\end{array}$ & $\begin{array}{c}\text { P-506L } \\
\text { (高抵抗) }\end{array}$ \\
\hline 体 積 固 有 抵 抗 值 & 1.0 & 25.0 & 250.0 \\
\hline 組 成 (重量部) & & & \\
アセチレンブラック粒径 $40 \mathrm{~m} \mu$ & 0.55 & 0.75 & 0.75 \\
ファーネスブラック粒径 $20 \mathrm{~m} \mu$ & 2.75 & 0.75 & 0.75 \\
グラファイトカーボン粒径 $2.7 \mathrm{~m} \mu$ & 2.2 & 0.75 & 0.75 \\
シリ カ 微 粉 末 & - & 1.5 & 1.5 \\
アクリレートオリゴマー & 4.0 & 4.0 & 6.0 \\
反 応 性 希 釈 剂 & 16.0 & 16.0 & 16.0 \\
接 着 促 進 剂 & 1.0 & 1.0 & 1.0 \\
\hline
\end{tabular}

注）アセチレンブラック，ファーネスブラックはカーボンブラックの種類を表す。

\subsection{1 導電性フィラー}

従来の抵抗ペーストと同じく, 導電性カーボンブ ラックを主として用いた。導電性がよいという事の ほかに，吸油性のあまり高くないもの，平均粒径20 $\mathrm{m} \mu$ 程度のもの, 抵抗温度係数の低いもの等が好結 果が得られた。また，抵抗值を調節するために，粒 径数 $\mathrm{m} \mu$ のグラファイトや, 絶縁性のシリカ粉など を混合した。

\subsection{2 バインダー}

電子線硬化型抵抗ペーストのバインダーの中には, 電子線硬化型オリゴマー, 反応性希釈剂, 摇変性調 節剂や接着性改良剂等の添加剂が含まれている。

電子線硬化型オリゴマーとして代表的なものは, アクリレート系 (ラジカル重合), 不飽和ポリエス テル系 (ラジカル重合), チオールエン系 (ラジカ ル重合)，エポキシ系（カチオン重合）等があるが, 塗料，インキ等の分野と同じくアクリレート系のオ リゴマーが使いやすい。乙れは，ポリアクリル酸エ ステル等のオリゴマーの末端または側鎖に（メタ） アクリロイル基を導入したもので, これに電子線を 照射すると，エチレン性二重結合が開裂して遊離ラ ジカルを生成, 連鎖的に重合, 架橋反応が進行して 網状高分子化するととになる。

反応性希釈剂としては（メタ）アクリロイル基を 有する低分子化合物を用いたが，乙れはぺーストの 流動性を改善すると共に，電子線照射によって反応 してバインダーマトリックスの一部となる。

以上のほかに, ペーストのチクソトロピーや, 基 板との密着を改善するための添加剂を加えることは 従来型のペーストと同じである。

電子線硬化型抵抗ペーストに打ける上記 3 成分の 比率はぺーストの使用目的によって変化させた。

\section{2 抵抗ペーストの諸特性}

従来の熱硬化型抵抗ペーストにおける導電性フィ ラーの濃度と抵抗值との関係, 同フィラーに打ける 導電のメカニズム，ペースト組成とレオロジー的性 質との関係等については, 既に多くの報告があるが ${ }^{4}$, 本実験において使用した電子線硬化型抵抗ペースト の場合にも, 熱硬化型ペーストのカーボンブラック の充てん量と抵抗值の関係グラフ（図 1) のように なり,同様にあてはまると考える。 


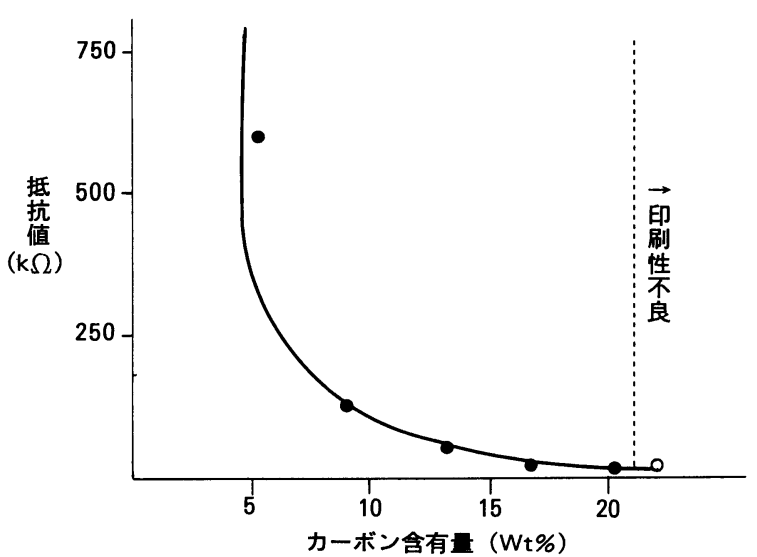

図 1. 無溶剂型接点ペーストにおけるカーボンブラック の充てん量と抵抗值の関係 $(1.0 \mathrm{~mm} \times 10.0 \mathrm{~mm})$

また，電子線硬化型抵抗ペーストの特性を表 2 亿示す。 印刷抵抗では抵抗值の調節は, 抵抗体のアスペク 卜比(長さと幅・図 2 参照)を変えることによって行 われるが, 前述のペーストについてはアスペクト比 と抵抗值との間に直線関係のあることが確認されて いる。(表 3 ・図 3 参照)

\section{4. 本技術に必要な電子線照射装置}

\section{1 電子線照射装置の概要}

電子線照射装置は, 各種プラスチックの改質, ゴ ムの架橋, イオン交換膜の製造, 塗膜の硬化分野に おいて使用され, 装置の定格としては $200 \mathrm{keV}$ 級の

表 3. アスペクト比と抵抗値との関係

\begin{tabular}{|c|c|c|c|c|c|c|c|c|c|}
\hline \multicolumn{5}{|c|}{ 抵抗体パターン $1 \mathrm{k} \Omega / \square$} & \multicolumn{5}{|c|}{ 抵抗体パターン $1 \mathrm{k} \Omega / \square$} \\
\hline No. & $\mathrm{L}_{\mathrm{m}}$ & $\mathrm{W}_{\mathrm{m}}$ & $\begin{array}{l}\text { アスペ } \\
\text { クト比 }\end{array}$ & 抵抗值 $\Omega$ & No. & $L_{m}$ & $\mathrm{~W}_{\mathrm{m}}$ & $\begin{array}{l}\text { アスペ } \\
\text { クト比 }\end{array}$ & 抵抗值 $\Omega$ \\
\hline 1 & 0.5 & 1.0 & 0.5 & 486 & 16 & 1.6 & 1.4 & 1.14 & 1078 \\
\hline 2 & 0.5 & 1.4 & 0.36 & 343 & 17 & 1.6 & 1.8 & 0.89 & 811 \\
\hline 3 & 0.5 & 1.8 & 0.28 & 269 & 18 & 1.6 & 2.0 & 0.80 & 778 \\
\hline 4 & 0.5 & 2.0 & 0.25 & 224 & 19 & 1.6 & 2.4 & 0.67 & 643 \\
\hline 5 & 0.5 & 2.4 & 0.21 & 198 & 20 & 1.6 & 2.8 & 0.57 & 529 \\
\hline 6 & 0.5 & 2.8 & 0.18 & 166 & 21 & 1.6 & 3.2 & 0.50 & 467 \\
\hline 7 & 0.5 & 3.2 & 0.16 & 142 & 22 & 2.0 & 1.0 & 2.00 & 1882 \\
\hline 8 & 1.0 & 1.0 & 1.00 & 877 & 23 & 2.0 & 1.4 & 1.42 & 1337 \\
\hline 9 & 1.0 & 1.4 & 0.71 & 751 & 24 & 2.0 & 1.6 & 1.25 & 1124 \\
\hline 10 & 1.0 & 1.8 & 0.56 & 527 & 25 & 2.6 & 1.0 & 2.60 & 2527 \\
\hline 11 & 1.0 & 2.0 & 0.50 & 473 & 26 & 2.6 & 1.4 & 1.85 & 1743 \\
\hline 12 & 1.0 & 2.4 & 0.42 & 402 & 27 & 2.6 & 1.6 & 1.63 & 1562 \\
\hline 13 & 1.0 & 2.8 & 0.38 & 363 & 28 & 3.2 & 1.0 & 3.28 & 3133 \\
\hline \begin{tabular}{|l|}
14 \\
\end{tabular} & 1.0 & 3.2 & 0.31 & 287 & 29 & 3.2 & 1.4 & 2.28 & 2137 \\
\hline 15 & 1.6 & 1.0 & 1.60 & 1442 & 30 & 3.2 & 1.6 & 1.50 & 1442 \\
\hline
\end{tabular}

表 2. 使用抵抗ペーストの特性

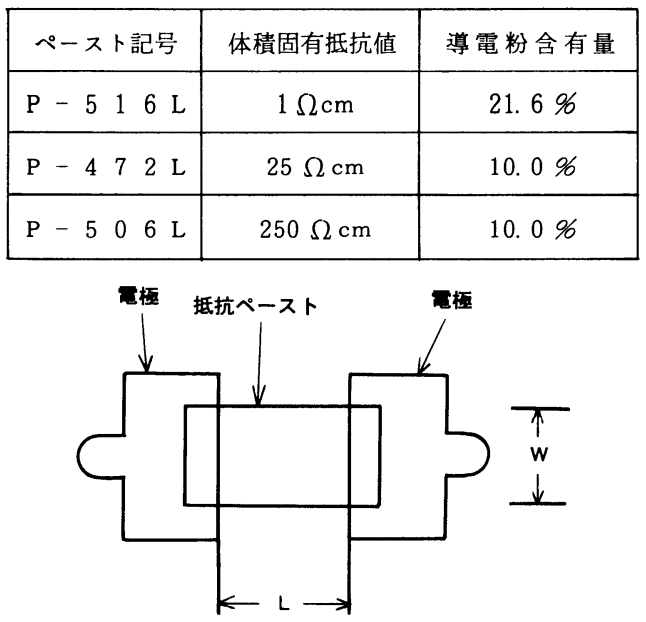

図 2. 抵抗值のアスペクト比 $(L / W)$

低エネルギーから $3000 \mathrm{keV}$ 級の高エネルギーのあ のがあるが，プリント配線板の塗膜の硬化のように。 塗布膜が数十 $\mu \mathrm{m}$ 程度のものには低エネルギーの電 子線照射装置で十分と思われる。

\section{2 電圧定格}

電子が物質に透過する能力は, 電子線照射装置の 電圧定格, 照射条件, 被照射物の比重によって決ま る。

一般に, 電子線照射装置の電圧定格は, 真空中に て電子が加速される最大エネルギーで表示され, 加 速された電子は被照射体中で, 一定の距離を透過し

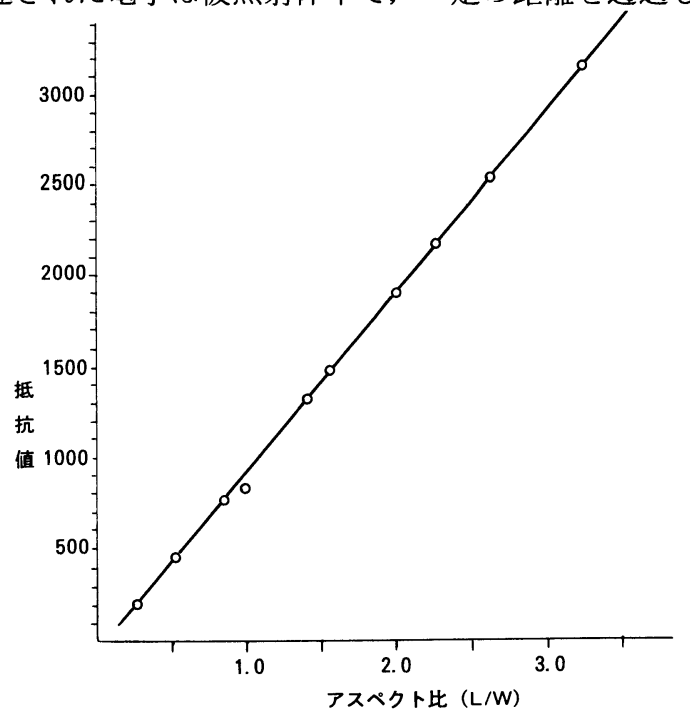

図 3.アスペクト比と抵抗值との関係グラフ 


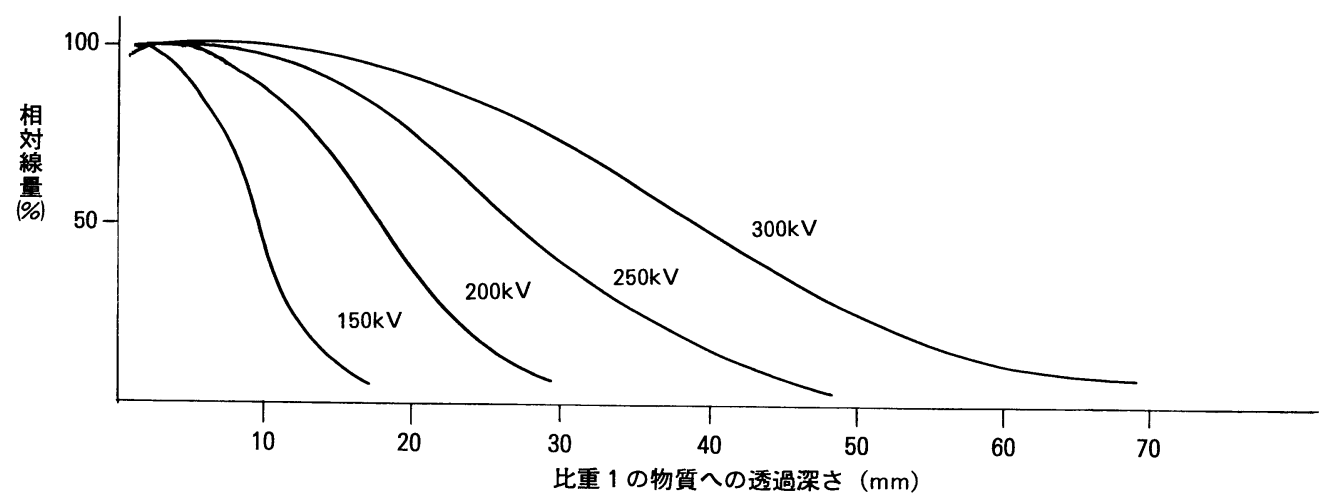

図 4. 電子線透過能力曲線

て全エネルギーを失う。乙れらの関係は種々の物質 について Spencer ${ }^{5)}$ らよって求められている。

こてで仮に, 比重 1 なる物質中に照射した場合 の, 加速電子の透過深さと物質中の相対的エネルギ 一損失 (吸収線量) との関係を図 4 亿示す。

横軸は比重 1 の物質への透過深さ $(\mathrm{mm})$, 縦軸は 相対線量（相対イオン化強度)であるが, 比重 $\rho(\mathrm{g} /$ $\left.\mathrm{cm}^{2}\right)$, 厚さX (mm) の物質に照射する場合に必 要な加速電圧を求めるには, 横軸を $\rho$ 分の 1 倍し, 電子線透過能力曲線の最大値の交点の横軸の読み （有効透過能力）がX（mm）より大きくなるような 電圧を選択する。

\section{3 電流定格}

硬化処理速度は, 必要な吸収線量と電子流（電流 値）によって決定される。

照射処理量は, 表面照射の場合, 装置の電子線走 查幅をW $(\mathrm{cm})$, 被照射物の異動スピードを $\mathrm{V}(\mathrm{cm} /$ $\mathrm{sec})$, 電子流を I ( $\mathrm{mA})$, 電子流の利用効率を $\eta$ とすれば, 被照射物の吸収線量 D（Mrad）との間 には,

$$
\begin{aligned}
& \mathrm{D}=\frac{\Delta \mathrm{E}}{\Delta \mathrm{R}} \cdot 100 \frac{\eta \mathrm{I}}{\mathrm{VW}} \\
& \Delta \mathrm{E}: \text { エネルギー損失 }(\mathrm{eV}) \\
& \Delta \mathrm{R}: \text { 非照射物の厚み }\left(\mathrm{mg} / \mathrm{cm}^{2}\right) \\
& \Delta \mathrm{E} / \Delta \mathrm{R}: \text { 平均エネルギー損失 }
\end{aligned}
$$

なる関係がある。乙こで（ $\Delta \mathrm{E} / \Delta \mathrm{R}$ ）は加速電圧 $\mathrm{E}(\mathrm{KeV})$ に応じて変化する平均值エネルギー損失 であり,てれを表 4 亿示す。

\begin{tabular}{|c|c|}
\hline $\mathrm{E}(\mathrm{keV})$ & $\Delta \mathrm{E} / \Delta \mathrm{R}$ \\
\hline 100 & 7.0 \\
\hline 200 & 4.1 \\
\hline $\begin{array}{lll}3 & 0 & 0\end{array}$ & 3. 6 \\
\hline 400 & 3.2 \\
\hline 500 & 2.9 \\
\hline 750 & 2.5 \\
\hline 1000 以上 & 2.0 \\
\hline
\end{tabular}

したがって, 表面処理量 $\mathrm{S}\left(\mathrm{m}^{2} / \mathrm{min}\right)$ は,
表 4. 加速エネルギー $\mathrm{E}$ と平均エネルギー損失 率 $(\Delta \mathrm{E} / \Delta \mathrm{R})^{7)}$ の関係

$\mathrm{S}=\mathrm{V} \cdot \mathrm{W} \times 6 \times 10^{-3}=0.6 \frac{\Delta \mathrm{E}}{\Delta \mathrm{R}} \cdot \frac{\eta \mathrm{I}}{\mathrm{D}}$ となる。

\section{4 必要なビームの形状}

工業的に用いられている電子線照射装置の多くは, スポット状の電子ビームを被照射物の進行方向之直角 に，すなわち被照射物の幅方向に走查する方式が採 用されているが, 本報告のものは, 非走查形といわ れる照射幅に見合った幅にフィラメントを並列配置 し, 電子的には直列に接続して電子を面状に, いわ ゆるエリアビーム状に放出するエリアビーム形を採 用した。非走査形の線形のフィラメントから帯状の

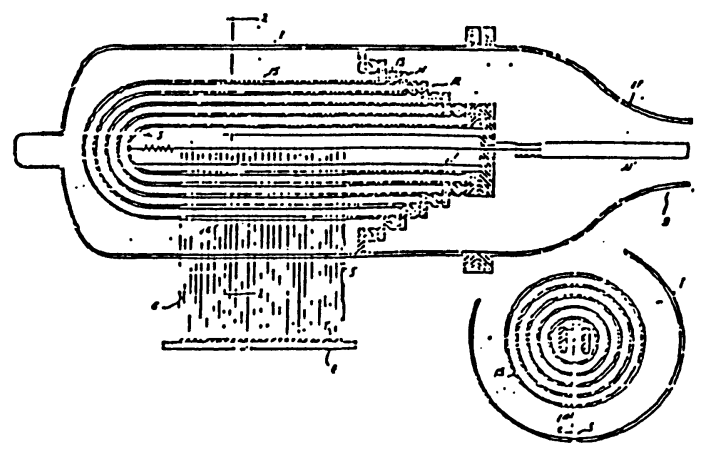

図 5. 線形フィラメントの基本アイディア 
電子ビームを発生するてのアイデアは, 1959年に アメリカ HVEC社のDr.Trump ${ }^{8)}$ が考案した電子加 速管 (図 5 参照 $)^{9)}$ に見られるごとく古くからある あのである。

非走查形は, 装置の高さを低くする事が出来, 通 常の室内に収納出来るので採用した。

\section{5. 実験に用いた装置の構成}

エリアビーム形電子線照射装置は, 図 6 のブロッ ク図に示すように次の部分より構成される。

(1) 直流電源部

(2) 加速装置部

(3) 搬送装置部

(4) 制御装置部

\section{1 直流電源部}

商用周波電圧を, 3 相倍電圧整流回路にて直流高 電圧に変え加速電圧を得ている。電子線源への電力 供給は絶縁変圧器を用い, その 1 次側電圧を制御し フィラメントの加熱電力をコントロールした。

直流電源部は鉄製タンクに収納, 絶縁用 S F 6 ガ スを封入し, 絶縁の高信頼性と小型軽量化を図って いる。

\section{2 加速装置部}

概略構成を図 $7^{11)}$ に示す。

円筒形ステンレス製真空容器の内側中央にカソー ドフィラメント, 下方に電子線を取り出す照射空を 配置した。電子線は, 照射空の金属箔を通して, 大 気, または $\mathrm{N}_{2}$ ガスを中に放出される。真空容器内 部のカソードフィラメント部は, 高電圧絶縁を保持 するためのコロナシールドで覆い電界を緩和してい る。電子線が金属箔を通過するときエネルギーロス を生じ, 熱に変換されるので金属箔は水冷パイプで 支持する方式を採用している。

フィラメントおよび金属箔は寿命により，また， 金属箔は塗布レジンの揮発成分が付着するので定期 的に取り換えることが必要で, てれらの交換作業が 装置の前面から簡単に行えるように考慮した。容器 内部は, 高真空に保つために高排気量の真空ポンプ およびドライ真空を確保するための高性能クライオ ポンプを採用し，そのバルブ操作む自動プログラム

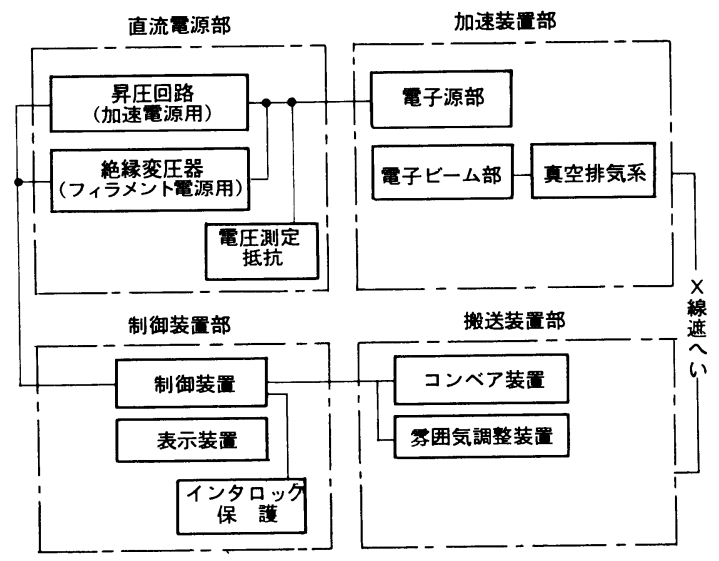

図 6. 装置ブロック図 ${ }^{10)}$

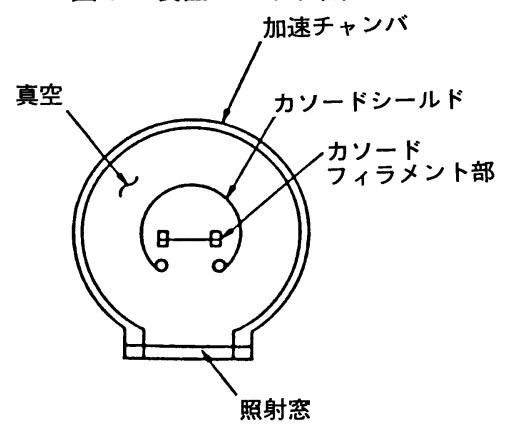

図 7. 加速装置部

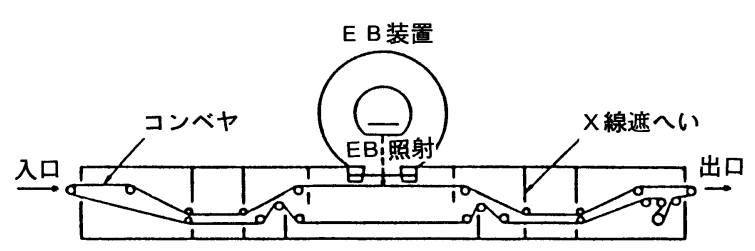

図 8. 搬送コンベア

によって行うシステムとし, 運転の容易な方式とし ている。

\section{3 搬送装置部}

各種サイズのプリント配線板を連続して搬送する が, 搬入・搬出口からX線が洩れないよう, 図 $8^{12)}$ に示すように搬入・搬出側のコンベアに傾斜をつけ ている。また, 斜面でプリント配線板がスリップし ないよう緩やかな角度を持つステンレス製メッシュ コンベアを採用した。

\subsection{X線遮へい}

加速された電子線が物質に当たって発生するX線 は, 人体に対し有害であるので適切な X 線遮へいを 施さなければならない。本装置は, $300 \mathrm{keV}$ の低 エネルギーであるので遮へい材として鉛と鉄を使用 
し, 加速装置部と搬送装置部を包む自己シールド方 式とし, 装置の小型化と安全化を図った。

搬送装置部の傾斜部には鉛之鉄のバリヤーを置い て迷路方式にし, 漏洩 X線量は装置の全周辺に沶い て, 壁面から $10 \mathrm{~cm}$ 離れた所で $0.06 \mathrm{mR} / \mathrm{h}$ 以下にな るようにした。

更に，保守のため，搬送装置部側面は開閉扉を設 置した上にインターロックをとり，安全を確実なむ のにした。

\section{5 照射需囲気調整装置}

一般に, 電子線照射によるレジストインキ, 樹脂 のキュアリング反応はラジカル重合型が多いが, 照 射雾囲気に酸素が存在すると, 生成したラジカル酸 素と反応して重合反応が阻害される。そのため, 本 装置では照射雺囲気を $\mathrm{N}_{2}$ ガスで置き換え出来るよ うにした。

\section{6 制御装置部}

加速電压, 電子流, コンベアスピードともプリセ ットによる自動運転で連動運転が出来るようになっ ている。加速電圧は, 電圧測定抵抗に流れる信号と プリセットした設定信号とを比較して，その差に応 じて制御信号をサイリスタ式電力調整器の制御回路 に入力して出力電圧を制御している。電子流は, 負 荷電流による信号とプリセットした設定信号とが一 致するよう，制御信号をサイリス夕式電力調整器の 制御回路に入力して出力電力を制御し, フィラメン トの加熱をコントロールしている。所要の照射線量 が得られるよう, コンベア速度と電子流の組合わせ をあらかじめ同調設定するととができる。更に，装 置が正しい運転状態を維持し, 安全な運転をするた めのインタロック機構が設けられると共に, 装置の
動作状態を制御パネル面に表示して，簡単な操作を 可能にしている。

\section{6. 実験結果と考察}

本印刷抵抗ペーストの特長は, 樹脂とカーボンを 主成分とするととによって，スクリーン印刷法で形 成された抵抗体の, 硬化後の体積変化を最小限とな るように抑え, 抵抗值を一定の範囲内に設定出来る ようにしたてとである。実際には, 部品実装の工程 に扔いて, 素材の紙フェノール積層板の寸法安定性 の影響を受けやすいので, 印刷抵抗としては定格電 力 $1 / 32 \mathrm{~W}-50 \mathrm{~V}$ の抵抗值範囲 $100 \Omega \sim 100 \mathrm{k} \Omega$ に限 定し， 3 種類のペーストによりオーバーラップする 形でカバーするようにした。(図 9 参照)

更に部品実装時での環境信頼性試験に拈ける変化 率を最大 $20 \%$ 以下の許容差内に入るととを目標とし， 次の 6 項目につき試験を行った。試験項目と結果を 次に示す。なお, 各試験項目において, 得られた抵 抗を, 半田浸漬を $260 \pm 5{ }^{\circ} \mathrm{C}$ 亿て 5 秒間行い, その 後, 室温にて 3 時間放置後の抵抗值をむって初期值 としている。

(1) 高温高湿試験

$60^{\circ} \mathrm{C} ， 90 \sim 95 \mathrm{RH} \% ， 240 \pm 4$ 時間放置 $\rightarrow 60^{\circ} \mathrm{C}$ 乾 燥機中 1 時間土15分 $\rightarrow$ 室温にて30分放置後の抵抗值 変化率を測定した。その結果を表 5 に示す。

表 5. 高温高湿試験

\begin{tabular}{|c|c|c|c|c|c|c|}
\hline \multicolumn{3}{|c|}{ 抵抗体パターン } & \multicolumn{3}{|c|}{ 抵抗値変化率 $\%$} \\
\hline $\mathrm{N} 0$ & $\mathrm{Lmm}$ & $\mathrm{Wmm}$ & アスペクト比 & $\mathrm{P}-516$ & $\mathrm{P}-472$ & $\mathrm{P}-506$ \\
\hline 1 & 1.0 & 1.0 & 1.0 & 19.6 & 18.7 & 19.0 \\
\hline 2 & 1.0 & 2.0 & 0.5 & 20.7 & 18.5 & 17.0 \\
\hline 3 & 1.6 & 3.2 & 0.5 & 16.4 & 18.8 & 18.6 \\
\hline 4 & 2.0 & 1.6 & 1.25 & 17.0 & 16.8 & 18.4 \\
\hline 5 & 3.2 & 2.0 & 1.6 & 18.4 & 18.6 & 20.5 \\
\hline
\end{tabular}

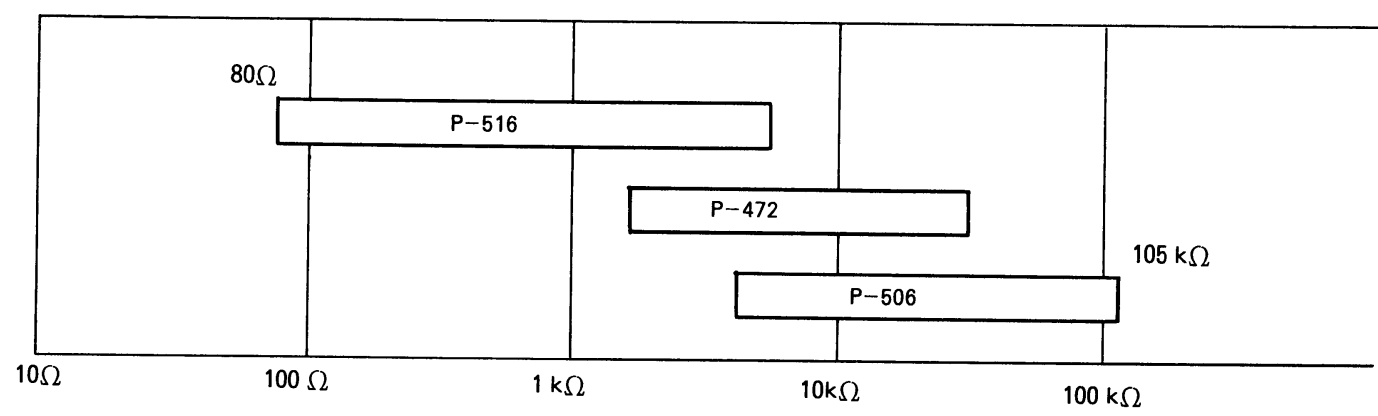

図 9. 抵抗值範囲 
（2）高温高湿負荷試験

$60^{\circ} \mathrm{C}, 90 \sim 95 \mathrm{RH} \%$ （定格電圧90分印加 $\rightarrow$ 無負荷 30分） $500 \pm 12$ 時間繰り返す $\rightarrow$ 室温無負荷 1 時間後 の抵抗値変化率を測定した。その結果を表 6 に示す。

表 6. 高温高湿負荷試験

\begin{tabular}{|c|c|c|c|c|c|c|}
\hline \multicolumn{3}{|c|}{ 抵抗体パターン } & \multicolumn{3}{c|}{ 抵抗値変化率 \% } \\
\hline $\mathrm{Na}$ & $\mathrm{Lmm}$ & $\mathrm{Wmm}$ & アスペクト比 & $\mathrm{P}-516$ & $\mathrm{P}-472$ & $\mathrm{P}-506$ \\
\hline 1 & 1.0 & 1.0 & 1.0 & 16.3 & 15.5 & 16.2 \\
\hline 2 & 1.0 & 2.0 & 0.5 & 10.8 & 17.7 & 16.7 \\
\hline 3 & 1.6 & 3.2 & 0.5 & 17.3 & 18.9 & 19.0 \\
\hline 4 & 2.0 & 1.6 & 1.25 & 16.6 & 15.9 & 18.1 \\
\hline 5 & 3.2 & 2.0 & 1.6 & 13.3 & 18.2 & 16.2 \\
\hline
\end{tabular}

(3) 高温寿命試験

$60^{\circ} \mathrm{C} \pm 2{ }^{\circ} \mathrm{C}, \quad 500 \pm 12$ 時間無負荷放置 $\rightarrow$ 室温に て 1 時間放置後の抵抗值変化率を測定した。その結 果を表 7 に示す。

表 7. 高温寿命試験

\begin{tabular}{|c|c|c|c|c|c|c|}
\hline \multicolumn{3}{|c|}{ 抵抗体パターン } & \multicolumn{3}{|c|}{ 抵抗值変化率 \% } \\
\hline Na & Lmm & Wmm & アスペクト比 & $\mathrm{P}-516$ & $\mathrm{P}-472$ & $\mathrm{P}-506$ \\
\hline 1 & 1.0 & 1.0 & 1.0 & 14.8 & 16.1 & 12.2 \\
\hline 2 & 1.0 & 2.0 & 0.5 & 10.3 & 13.6 & 11.3 \\
\hline 3 & 1.6 & 3.2 & 0.5 & 13.9 & 15.0 & 12.2 \\
\hline 4 & 2.0 & 1.6 & 1.25 & 13.8 & 12.4 & 14.7 \\
\hline 5 & 3.2 & 2.0 & 1.6 & 17.4 & 14.6 & 10.3 \\
\hline
\end{tabular}

（4） 高温寿命負荷試験

$60^{\circ} \mathrm{C} \pm 2{ }^{\circ} \mathrm{C}$, 定格電圧 90 分印加 $\rightarrow$ 無負荷 30 分, $500 \pm 12$ 時間繰り返す $\rightarrow$ 室温 1 時間放置後の抵抗值 変化率を測定した。その結果を表 8 亿示す。

表 8. 高温寿命負荷試験

\begin{tabular}{|c|c|c|c|c|c|c|}
\hline \multicolumn{3}{|c|}{ 抵抗体パターン } & \multicolumn{3}{|c|}{ 抵抗值変化率 \% } \\
\hline $\mathrm{Na}$ & $\mathrm{Lmm}$ & Wmm & アスペクト比 & $\mathrm{P}-516$ & $\mathrm{P}-472$ & $\mathrm{P}-506$ \\
\hline 1 & 1.0 & 1.0 & 1.0 & 16.2 & 13.6 & 9.4 \\
\hline 2 & 1.0 & 2.0 & 0.5 & 14.2 & 11.3 & 15.2 \\
\hline 3 & 1.6 & 3.2 & 0.5 & 9.5 & 15.6 & 11.4 \\
\hline 4 & 2.0 & 1.6 & 1.25 & 9.7 & 12.2 & 10.4 \\
\hline 5 & 3.2 & 2.0 & 1.6 & 14.4 & 14.9 & 16.2 \\
\hline
\end{tabular}

\section{（5）熱衝撃試験}

室温 $\rightarrow 30 \pm 5{ }^{\circ} \mathrm{C}$ (30分) $\rightarrow$ 室温（10 15分） $\rightarrow 85 \pm$ $5{ }^{\circ} \mathrm{C}$ (30分) $\rightarrow$ 室温 (10〜15分)を 5 サイクル繰り返 す $\rightarrow$ 室温 1 時間放置後の抵抗值変化率を測定した。 その結果を表 9 亿示す。

\section{表 9. 熱衝撃試験}

\begin{tabular}{|c|c|c|c|c|c|c|}
\hline \multicolumn{3}{|c|}{ 抵抗体パターン } & \multicolumn{3}{|c|}{ 抵抗值変化率 $\%$} \\
\hline No. & Lmm & Wmm & アスペクト比 & P-516 & P-472 & P-506 \\
\hline 1 & 1.0 & 1.0 & 1.0 & 18.7 & 16.5 & 14.3 \\
\hline 2 & 1.0 & 2.0 & 0.5 & 16.5 & 11.2 & 13.2 \\
\hline 3 & 1.6 & 3.2 & 0.5 & 17.1 & 10.9 & 14.9 \\
\hline 4 & 2.0 & 1.6 & 1.25 & 12.2 & 14.3 & 14.7 \\
\hline 5 & 3.2 & 2.0 & 1.6 & 17.4 & 11.2 & 11.2 \\
\hline
\end{tabular}

(6) P C T試験（プレッシャークッカーテスト）

$121 \pm 2{ }^{\circ} \mathrm{C}, 97 \% ， 2$ 気圧， 8 時間 $\rightarrow$ 室温 1 時間 放置後の抵抗值変化率を測定し, 表10にその結果を 示す。

表 10. P C T試験

\begin{tabular}{|r|c|c|c|c|c|c|}
\hline \multicolumn{3}{|c|}{ 抵抗体パターン } & \multicolumn{3}{|c|}{ 抵抗値変化率 \% } \\
\hline $\mathrm{N} 0$. & $\mathrm{Lmm}$ & $\mathrm{Wmm}$ & アスペクト比 & $\mathrm{P}-516$ & $\mathrm{P}-472$ & $\mathrm{P}-506$ \\
\hline 1 & 1.0 & 1.0 & 1.0 & 14.6 & 10.3 & 14.3 \\
\hline 2 & 1.0 & 2.0 & 0.5 & 12.8 & 12.6 & 14.8 \\
\hline 3 & 1.6 & 3.2 & 0.5 & 10.9 & 9.7 & 13.5 \\
\hline 4 & 2.0 & 1.6 & 1.25 & 13.0 & 11.4 & 18.1 \\
\hline 5 & 3.2 & 2.0 & 1.6 & 15.4 & 14.0 & 13.6 \\
\hline
\end{tabular}

表11は, 印刷完了後電子線を照射し硬化させた後 の抵抗值を示したものである。

\section{7. まとめ}

信頼性試験の結果, 電子線による硬化は従来の熱 硬化方式と比較して生産性, 性能経済性が高く, 変 化率も20\%以下と安定しているものが得られた。更 に機材のダメージを回避することも出来, 他のぺー

表 11. 硬化後の初期值

\begin{tabular}{|c|c|c|c|c|c|c|c|c|c|c|c|c|}
\hline \multirow{3}{*}{ 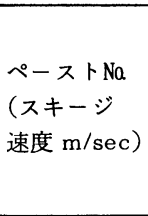 } & \multirow{2}{*}{\multicolumn{2}{|c|}{ パターン }} & \multicolumn{3}{|c|}{ Left } & \multicolumn{2}{|c|}{$\begin{array}{ll}\downarrow & \text { 即 } \\
w & \text { 刷 } \\
\cdots & \text { 方 } \\
& \end{array}$} & \multicolumn{3}{|c|}{ Right } & \multicolumn{2}{|c|}{ 印刷方向 $\rightarrow$} \\
\hline & & & \multicolumn{3}{|c|}{ 抵 抗 值 $(\Omega)$} & \multicolumn{2}{|c|}{ バラッキ } & \multicolumn{3}{|c|}{ 抵 抗 值 $(\Omega)$} & \multicolumn{2}{|c|}{ バラッキ } \\
\hline & $\mathrm{Na}$ & $\begin{array}{r}\mathrm{L}+\mathrm{W} \\
\mathrm{mm}\end{array}$ & 平 均 & Mix & $\operatorname{Max}$ & $\begin{array}{l}\text { Min } \\
(0)\end{array}$ & $\begin{array}{c}\operatorname{Max} \\
\text { (O) }\end{array}$ & 平 均 & Mix & $\operatorname{Max}$ & $\begin{array}{c}\text { Min } \\
(0)\end{array}$ & $\begin{array}{c}\operatorname{Max} \\
\text { (O) }\end{array}$ \\
\hline$P-516$ & 8 & $1 \times 1$ & 567 & 539 & 589 & -5.0 & +3.8 & 552 & 455 & 552 & -12.9 & +5.6 \\
\hline$(0.299)$ & 24 & $2 \times 2$ & 654 & 511 & 738 & -21.9 & +12.8 & 709 & 626 & 780 & -11.8 & +10.0 \\
\hline$P-472$ & 8 & $1 \times 1$ & $8.00 \mathrm{k}$ & 7. $11 \mathrm{k}$ & $8.87 \mathrm{k}$ & -11.1 & +10.9 & 8. $39 \mathrm{k}$ & 7. $71 \mathrm{k}$ & 9. $26 \mathrm{k}$ & -8.1 & +10.4 \\
\hline$(0.225)$ & 24 & $2 \times 2$ & 9. 53 & 8024 & 10. 29 & -13.5 & +8.0 & 12. 67 & 10. 69 & 14. 33 & -15.6 & +13.1 \\
\hline$P-506$ & 8 & $1 \times 1$ & $32.37 \mathrm{k}$ & $28.50 \mathrm{k}$ & $37076 \mathrm{k}$ & -12.0 & +10.5 & $30.75 \mathrm{k}$ & 29. $23 \mathrm{k}$ & $31.83 \mathrm{k}$ & -4.9 & +3.5 \\
\hline$(0.289)$ & 24 & $2 \times 2$ & 34.50 & 29. $50 \mathrm{~K}$ & 39. 50 & -14.5 & +14.5 & 38. 50 & 32.00 & 45. 00 & -16.8 & +16.8 \\
\hline
\end{tabular}


スト類あるいは樹脂の硬化（絶縁塗膜）あ可能であ り，プリント配線板の複合化技術に今後寄与し得る あの之思われる。

(1987.3. 30 - 受理)

1) 特開昭59-113602

2 ）特開昭 $60-88027$

3 ) 特開昭 $60-130895$

4 ）浅田泰司：“日本ゴム協会誌”, 58, (9) 572 (1985)

5 ) L.V.Spencer: "Energy Dissipation by Fast Electrons", National Bureau of Standards Monograph 1, Sep., 10 (1959)

6）日新電機技報, Vol. 31, No.4, 27 (1986-10)

7 ）日新ハイボルテージ：“工業用電子線照射装置”, NHV-4371, 26 (1982)

8) J.G.Trump: "Electron Acceleration Tube", June, 17 (1957)

米国特許, May, 19 (1959), J.G. Trump, No. 2887599

9 ）日新ハイボルテージ：“工業用電子線照射装置”, NHV-4371, 40 (1982)

10）日新電機技報，Vol. 31，No.4，29（1986-10)

11）日新電機技報，Vol.31，No.4，29 (1986-10)

12）日新電機技報，Vol. 31，No. 4, 30 (1986-10)

\section{第 1 回学術講演大会開催さる}

プリント回路学会第 1 回学術講演大会は,去る 3 月16, 17日の両日, 機械振興会館（東京都港 区芝公園）で開催された。

大会は, 安達芳夫会長の開会あいさつに始ま り，初日は，製造技術，パターン設計とC A D システム,アートワーク，実装技術の 4 分野で 16件の講演発表が行われ，活発な質疑応答が交 わされた。

また, 同日午後 4 時から東京大学生産技術研 究所・生駒俊明教授により「半導体技術の現状 と将来」と題する特別記念講演が行われ, プリ ント回路技術と密接に関連する半導体技術の将 来展望が示された。引き続き, 同 5 時半から同 会館 6 F 66号室にて懇親会を開催し, 約60名の 会員が参加して懇親を深めた。

大会 2 日目は，基板材料分野に始まり，八イ
ブリッド回路技術, 試験・検査, パターン形成 技術の 4 分野にわたって21件の講演発表が行わ れ, 午後 6 時半, 無事終了した。

大会には，2 日間を通して，合計 300 余名が 参加し, 会場加らあふれんばかりの盛況ぶりで あった。

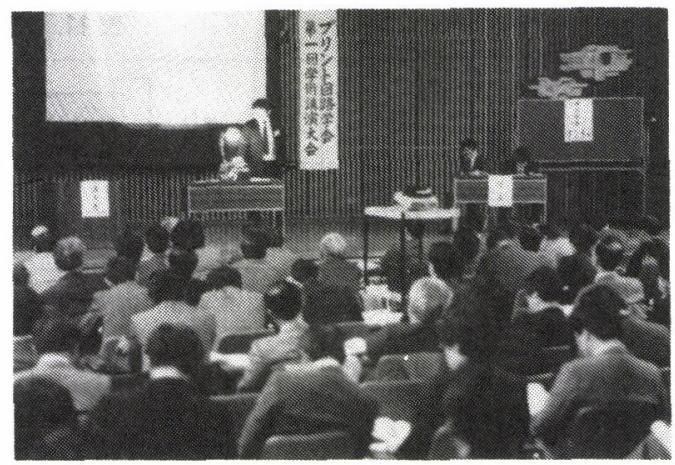

満員の会場に，発表者も熱意を込めて講演 